\title{
Frederick Mosteller (1916-2006): Mentoring, A Memoir
}

Frederick Mosteller was born in Clarksburg, West Virginia, at the time of the birth of medical technology assessment (10). During a long academic career at Harvard, he, probably more than any other person, contributed to techniques of assessment of therapy and outcome $(6 ; 14 ; 29)$. Much of his seminal writing was published in the International Journal of Technology Assessment in Health Care $(1 ; 3 ; 8 ; 12 ; 16 ; 17 ; 19 ; 21-$ 23).

On a cold, sleety night in November 1961, on Divinity Avenue, Cambridge, Massachusetts, I first met Professor Mosteller. I took a chance in accosting him, as the only description I had was "he is tubby and genial": the words of my boss Henry K. Beecher who suspected inadequacies of my experimental design. Mosteller heard me out and took me back to his office, where he gave me a copy of NonParametric Methods in Statistics (13), which he was presenting to the Harvard Library System. "Let us meet again when you have read it." The next morning at 7:00 AM, I reappeared in Mosteller's office. "Have you read it?" A tremulous, "Yes." "Then we can do business." Subsequently, Mosteller told me that one of the main reasons he devoted the next 2 hours to my study of lung collapse (2) was that he thought I was lying.

Fred Mosteller taught many of the senior faculty of the Harvard Medical School and was seminal in the birth of evidence-based medical and surgical practice. Surgeons B.A. Barnes and J.W. Raker; internists H. Hiatt, H.S. Frazier, and T.C. Chalmers; anesthesiologists Beecher and J.P. Bunker have all told me of his stupendous teaching and efforts on their behalf, and on behalf of all patients; placebos, analysis of surgical results, dentistry, melanoma treatment, tuberculosis management, anesthetic toxicity (the National Halothane Study), strategies to prevent and treat ischemic heart disease, and drug effectiveness in schizophrenia, were all advanced under Mosteller's tutelage $(4 ; 6 ; 7 ; 11 ; 18 ; 20)$. Acous-

J. Hedley-Whyte is supported by the David S. Sheridan Professorship in Anaesthesia and Respiratory Therapy, Harvard University. tical analysis of voice changes accompanying and following endotracheal intubation (27) and effectiveness of acupuncture (15) did not escape his interest. As late as 2006, the British Medical Journal named him as a key mentor in a study of acupuncture and placebos (15).

His knowledge of medicine was more complete than most physicians'. He used to say that he had acquired it as a patient, and indeed, he was seriously ill in middle age with gall bladder disease, leading to pancreatitis, peritonitis, and incipient respiratory failure. For the time he had spent teaching his surgical team at the Massachusetts General Hospital, Mosteller was rewarded by his subsequent good health.

Conducting a monthly seminar at 7:45 AM on Technology Assessment, Mosteller consistently demonstrated numerous traits: He liked the equations to be properly punctuated. He liked the audience and he himself to be able to interrupt, and the speaker to be unfazed and quick with repartee or critique. His own barbs often began with "Thank you, but what about..." Or when two or three such errors of omission or commission had been made, he soon thereafter appeared to fall asleep. Before the end, he raised further possible errors he had recognized. "Scholastic dreaming" he once called it. These seminars were chaired by Mosteller from 1970 to 2003, with the exception of 1975-76, which I chaired while he took a sabbatical at Stanford. Initially concerned with statistical analysis of technology performance, they were held in Harvard's Department of Statistics, and later they were held in the Longwood Medical Area, chiefly at the Harvard School of Public Health, and even later they reverted to the vicinity of Harvard Square. After his serious illness, Mosteller changed the name from Technology Assessment to Health and Medicine and then to Affordable and Effective Care. He told me that the complexity of his care at the Massachusetts General Hospital amazed him. He counted over seventy different personal healthcare providers. I replied that the typical patient with peritonitis leading to acute respiratory failure in a Harvard-associated hospital was 
cared for by over sixty physicians. Minutes were written on the seminars and they were valuable sources for the subsequent books Mosteller wrote or edited $(6 ; 14)$.

Did I notice any change in his conduct during the 34 years? His choice of breakfast foods became more abstemious and of wine more that of an oenophile. His wit, recall for the mot juste, the appropriate data set, names and references continued to sparkle undiminished. His entrance, nearly always on time, was magisterial, but somewhat slower in his late eighties.

In private, or with our wives, he was remarkably trenchant. Ph.D. candidates were "Promising"- - his highest accolade; "No problem", "A struggle", or, he would say, "Not worth writing with." Virginia, his wife, always said "Not worthy."

In consultations outside the seminar, the questions he asked were often about his own work: "Who controlled access to the M.D. theses of Cambridge in relation to tuberculosis and BCG? (11)" "Were they catalogued?" "Why did R.A. Fisher get it wrong about smoking?" "Did Fisher smoke?" How many variables could one name that might influence the outcome of a siege during the Crusades? Mosteller's knowledge of Byzantine history was considerable, and he always liked to learn more. "What influence did Sir Steven Runciman's upbringing have on his writing?" he asked.

Mosteller was always interested in discussing the foibles of assessment of education. "Why did Finns do so well, especially in mathematics? It is easy compared with Finnish." "Were Harvard students with a wide range of grades better prospects for a successful career? Probably there is a lot to be said for concentrating on what you are good at." "Why are so many leading young scientists born Chinese? Population base and ethos." "Do professors at research universities become less productive of good research as they age? Pure mathematicians probably, others I am not sure." There followed from Mosteller a long monologue on his investigations into this controversy. Older research professors become more generous in assigning or even declining authorship. Being better known, their names on papers probably raise the impact factor, but young aspiring academics should also cultivate young colleagues who will later write assessments. Mosteller was unclear what a research professor in the health sciences should do except to "Study and assign the unsolvable; all really important societal problems are insoluble, but most are ameliorable." "Ameliorable" means persuasion and politics. Mosteller would rate his experience of the efficiency of the White House Cafeteria and compare it with the effectiveness of the Executive Branch. His experience on the Truman-Dewey poll forecast inquiry (26) gave perspective. When discussing the role of a professor in suspecting plagiarism, he said to himself it was like his determining the authorship of the Federalist Papers (24). "Writing styles were unique, but sample size was important."

Detection of lies interested Mosteller. Sissela Bok's book (5) was admired but polygraphs were unpredictable. Having performed a statistical analysis of the Kinsey Report (9), he struggled to make pollsters and scientists pay ever more attention to deception. Watching election results together, he would exuberantly express delight when the exit polls were confounded. On 28 October 2004, the morning after the Red Sox clinched the World Series, I opened the Seminar by drawing attention to the previous Sunday's New York Times article, "It's a Flip of the Coin", by Alan Schwarz (28). The seminal reference, "The World Series Competition," had been published by Mosteller in the September 1952 issue of the Journal of the American Statistical Association (25). After re-reading, Mosteller later said that the last half century seemed to have vindicated his conclusions. By this time, he had moved to Washington, D.C.

Throughout his mentoring, Mosteller was a good listener. Female students and colleagues were, if anything, given even more consideration. In the course of writing papers on low-back pain $(3 ; 22)$, Mosteller, who questioned political correctness, was delighted to be told that our coauthor and my Harvard successor, Carol Warfield, a Tufts Engineering and Medicine graduate, had been recruited while Carol and I were waltzing. He was even more delighted to be told by Carol, that my wife, a fellow Harvard Professor, had, at the same dance won a Charleston contest with the donor of my chair: "Enough to make you lose weight," said Fred Mosteller, who died on 23 July 2006, at the age of 89.

Fred Mosteller was a valued member of the Editorial Board of the Journal for many years.

\section{John Hedley-Whyte \\ Harvard University}

\section{REFERENCES}

1. Adams ME, Antczak-Bouckoms A, Frazier HS, et al. Assessing the effectiveness of ambulatory cardiac monitoring for specific clinical indications. Introduction. Int J Technol Assess Health Care. 1993;9:97-101.

2. Bendixen HH, Hedley-Whyte J, Laver MB. Impaired oxygenation in surgical patients during general anesthesia with controlled ventilation. A concept of atelectasis. $N$ Engl J Med. 1963;269:991-996.

3. Bentkover JD, Sheshinki RH, Hedley-Whyte J, Warfield CA, Mosteller F. Lower back pain. Laminectomies, spinal fusions, demographics and socioeconomics. Int J Technol Assess Health Care. 1992;8:309-317.

4. Berkey CS, Antczak-Bouckoms A, Hoaglin DC, Mosteller F, Pihlstrom BL. Multiple-outcomes meta-analysis of treatments for periodontal disease. J Dent Res. 1995;74:1030-1039.

5. Bok S. Lying: Moral choice in public and private life. 1st ed. New York: Pantheon Books; 1978, xxii, 326 p.

6. Bunker JP, Barnes BA, Mosteller F, eds. Costs, risks and benefits of surgery. New York: Oxford University Press; 1977, xxv, $401 \mathrm{p}$.

7. Bunker JP, Forrest WH, Mosteller F, Vandam L, eds. The National Halothane Study: A study of the possible association between halothane anesthesia and postoperative hepatic necrosis. 
Washington, DC: U.S. Government Printing Office; 1969, ix, 418.

8. Burdick E, McPherson M-A, Mosteller F, eds. Special section: The contribution of medical registries to technology assessment. Int J Technol Assess Health Care. 1991;7:123-199.

9. Cochran WG, Mosteller F, Tukey JW. Statistical problems of the Kinsey Report. J Am Stat Assoc. 1953;48:673-716.

10. Codman EA. A study in hospital efficiency: As demonstrated by the case report of the first five years of a private hospital. Boston: Th Todd Co.; c. 1918, 179 p. (This work was originally privately published in 1912 and was reprinted in 1996 by the Joint Commission on Accreditation of Health Care Organizations, Oakbrook Terrace, IL).

11. Colditz GA, Brewer TFR, Berkey CS, et al. Efficacy of BCG vaccine in the prevention of tuberculosis. Meta-analysis of the published literature. JAMA. 1994;271:698-702.

12. Colditz GA, Miller JN, Mosteller F. Measuring gain in the evaluation of medical technology. The probability of a better outcome. Int J Technol Assess Health Care. 1988;4:637-642.

13. Fraser DAS. Nonparametric methods in statistics. New York: Wiley; 1957, x, $299 \mathrm{p}$.

14. Frazier HS, Mosteller F, eds. Medicine worth paying for: Assessing medical innovations. Cambridge, MA: Harvard University Press; 1995, xiv, 311p.

15. Kaptchuk TJ, Stason WB, Davis RB, et al. Sham device v inert pill: Randomized controlled trial of two placebo treatments. BMJ. 2006;332:391-397.

16. Klawansky S, Berkey C, Shah N, Mosteller F, Chalmers TC. Survival from localized breast cancer. Variability across trials and registries. Int J Technol Assess Health Care 1993;9:539553.

17. Laird NM, Mosteller F. Some statistical methods for combining experimental results.Int J Technol Assess Health Care. 1990;6:5-30.
18. Lasagna L, Mosteller F, von Felsinger JM, Beecher HK. A study of the placebo response. Am J Med. 1954;16:770-779.

19. Lasch K, Maltz A, Mosteller F, Tosteson T. A protocol approach to assessing medical technologies. Int J Technol Assess Health Care. 1987;3:103-122.

20. Lau J, Antman E, Jimenez-Silva J, et al. Cumulative metaanalysis of therapeutic trials for myocardial infarction. $N$ Engl J Med. 1992:327:248-254.

21. McPeek B, Mosteller F, McKneally M. Randomized clinical trials in surgery. Int J Technol Assess Health Care. 1989;5:317332.

22. Milamed DR, Warfield CA, Hedley-Whyte J, Mosteller F. Laminectomy and the treatment of lower-back pain in Massachusetts. Int J Technol Assess Health Care. 1993;9:426-439.

23. Mosteller F, Burdick E. Current issues in health care technology assessment. Int J Technol Assess Health Care. 1989;5:123136.

24. Mosteller F, Wallace D. Inference and disputed authorship: The Federalist Papers. Reading, MA: Addison-Wesley Publishing Co; 1964, 287 p.

25. Mosteller F. The world series competition. J Am Stat Assoc. 1952; 47:355-380.

26. Mosteller F. The pre-election polls of 1948. Social Science Research Council (U.S.) Bulletin 60. New York: Social Science Research Council; 1949, 396 p.

27. Priebe HJ, Henke W, Hedley-Whyte J. Effects of tracheal intubation on laryngeal acoustic waveforms. Anesth Analg. 1988:67:219-227.

28. Schwarz A. Winning team and best team? It's a flip of the coin. New York Times, October 24, 2004, Section 8, p. 13, Column 1.

29. Warren KS, Mosteller F, eds. Doing more good than harm: The evaluation of health care interventions. Annals of the New York Academy of Sciences, v.703. New York: New York Academy of Sciences; 1993, xii, $341 \mathrm{p}$. 